\title{
The use of particle size distribution integrated with consistency limits for experimentally simulating fine-grained sedimentary units
}

\author{
Wisam Razzaq Muttashar ${ }^{1}$ (I) - Lindsey Sebastian Bryson ${ }^{2} \cdot$ Zainab Abdelretha Al-Humaidan $^{1}$
}

Received: 10 June 2021 / Accepted: 29 October 2021 / Published online: 12 November 2021

(c) Saudi Society for Geosciences 2021

\begin{abstract}
The current study hypothesizes that reproducing sediment units that might belong to areas difficult to reach, sample, and attest is experimentally possible. The research aims to employ available sediment samples named source soils that can easily approach and sample to mix, simulate, and produce the (non-available) sedimentary units named Target Sediment Units (TSU). The particle size distribution (PSD) percentages are essentially used in the mixture procedure to construct the non-available (target) units (TSU). Several sedimentary units were targeted, designed, and simulated; They include marsh, bay mud, and natural levee sediment units selected from the eastern Basrah side at the lower Mesopotamian plain, southern Iraq. The matching between particle size distribution (PSD) curves of simulated sediment units (SSU) and target sediment unit (TSU) was verified by applying a developed slope proximity ratio. For the three tested sediment units (marsh, buy mud, and natural levee), the ratios of slope proximity were 1.0, 0.93, and 0.99, respectively, which are well matched. For the mineralogy, the consistency limits were used as a proxy. The Casagrande plasticity chart was modified to reveal two empirical functions linking the plasticity indices to the clay mineral groups. The two predictions are reliable means to proxy the mineralogy of the fine-grained sediments. Reconstructing procedure allows the non-available sediment samples to be practically presented and it better characterizes the sediment for forensic geoscience applications; for instance, engineering geology and sedimentology applications concerning with studies of the physical and mechanical behaviors of sediments and the depositional conditions interpretations, respectively.
\end{abstract}

Keywords Mixture procedure $\cdot$ Simulation $\cdot$ Particle size distribution $\cdot$ Sedimentary environments $\cdot$ Mesopotamian plain . Basrah · Southern Iraq

Responsible Editor: Amjad Kallel

Wisam Razzaq Muttashar

wisam.muttashar@uobasrah.edu.iq

Lindsey Sebastian Bryson

sebastian.bryson@uky.edu

Zainab Abdelretha Al-Humaidan

zainab.hamed@uobasrah.edu.iq

1 Marine Geology Department, Marine Sciences Center, University of Basrah, Basrah, Iraq

2 Hardin-Drnevich-Huang Professor of Civil Engineering, Department of Civil Engineering, University of Kentucky, 161 Raymond Bldg., Lexington, KY 40506, USA

\section{Introduction}

Nowadays, restrictions of the COVID-19 pandemic and the preventive measures or lack of the security of unstable areas subjected to wars cause remarkable disruptions to implement field sediment works across the world at survey and sample regions. The current research hypothesizes that reproducing sediment that might belong to areas difficult to reach, sample, and attest is experimentally possible. The proposition is a possibility to employing available sediment samples, called source soils in this study, that can easily approach and sample to generate non-available targeted sedimentary units having mainly particle size distribution data. However, due to the complexity of the components of sedimentary units, it is a challenge to simulate and model them (Brierley and Fryirs 2013 and Muttashar 2019). It is of major importance to simplify the complexity of these components that mainly refer to the sediment particle size and mineralogical 
composition. The movement aspects of sediments, such as deposition and transport, are essentially pertinent to the particle size (Cheng and Liu 2015). Many sedimentological and hydromorphic studies (van B Weaver and Stone 1980; Edmonds and Slingerland 2010; Beierle et al. 2002; Caldwell and Edmonds 2014; Zhu et al. 2014; Allen et al. 2015; Allen et al. 2017; Feng et al. 2017; Zhang et al. 2017; Gammoudi et al. 2019; Azidane et al. 2021) have attempted to identify the sedimentation process and the hydromorphic evolution through using and modeling sediment types and their particle size. Hence, the basic framework of sediment is fundamentally portrayed by the particle grain size (PSD) and mineralogical composition. The PSD, referring to the percent by weight finer than a given sieve size plotted as a function of the various grain size distribution in a sediment specimen (Hunt 1984), is considered the basis for soil classification systems and characteristics of different sediment units. In the sedimentological, geo-engineering, and geotechnical context, to experimentally study effects percentages of the particle sizes on physical and mechanical properties of sediments, mixture percentages of the main divisions, such as sand or/and fines (silt and clay) fractions have been often undertaken, yet those divisions cannot represent the whole shape of PSD curve that characterizes the sedimentary unit. The plausible guide that uncovers a reliance on particle size properties and depositional conditions is the shape of the PSD curve (or called the measured slope of the PSD curve) (Hunt 1984). The PSD curves are features of the geologic processes and can be utilized to estimate the depositional conditions and construct the sedimentary unit. It is therefore required to employ elements of the whole PSD curve (PSD shape) that not only include the primary divisions of sand, silt, and claypercentages but also integrate the (secondary) subdivisions.

Regarding the study area, the eastern Basrah side located in the lower southern Mesopotamian plain in Iraq reveals diversity in terms of the Holocene sedimentary environments. The region brings about various interaction fluvialestuarine sediment units system, such as flood plain, natural levees, marshes, and tidal flat sediment units. It, therefore, makes the region preferable of the current research where the particle size is the most crucial agent to discern those sedimentary units (Aqrawi 1993a). Most sedimentary units of the eastern Basrah part are fine-grained sediments. Thus, the component of the mineralogical composition is an essential second component alongside the particle size aspect. In this case, the plasticity parameters, such as liquid limit, plasticity index, and activity of the clays, are practical proxies applied to identify the mineralogy of the sediments (Muttashar et al. 2020; (Polidori 2007).

The current research aims to experimentally reproduce sedimentary units by emphasizing on estuarine and riverine sediment units selected from the eastern Basrah region, such as tidal flats, bay mud, and natural levee units. This experimental simulation approach serves to construct sediment samples representing sediment units of areas that might be difficult to reach and sample through using available sediment units. For instance, the current challenges and discontinuation that researchers have been facing causing disruptions to implement field sediment work of a certain required region across the world.

Reconstructing the entire PSD curve elements of the sedimentary unit, is a step forward towards better characterizing the sediment type experimentally for important geoscience purposes. Engineering geology and geotechnical purposes oftentimes study the physical and mechanical properties behaviors of sediments, in addition to the sedimentological applications that are interested in interpretations of the depositional conditions related to the statistical parameters of the particle sizes (including median, standard deviation (sorting), and skewness) (Blott and Pye 2001; Yang et al. 2009; Azidane et al. 2021)..

\section{Sediment structure overview}

In this paper, the term of the sediment (or sedimentary) unit refers to a basic framework of the inorganic sedimentary environment composed of particle size distribution curve (PSD) and mineralogical composition. The current study hypothesizes that the first step to mimic a required sedimentary environment, such as tidal flat or bay mud units, is to start the simulation of its PSD curve. Muttashar et al. (2020) were able to create a variety of controlled particle size distribution curves. They experimentally tended to control fines, silt, and clay percent, and subsequently, their method allows to study effects of material properties on the important physical and mechanical behavior of sediments (Muttashar et al. 2019; Muttashar and Bryson 2020). In this study, their methodology was developed to simulate real (targeted) sedimentary units experimentally, as demonstrated in the next section of materials and methods. To do so, the PSD curve of the target (real) sediment unit (TSU), referred to as a sediment unit required for reproducing, should be available either from the literature or tested. The study then proposed at least two other actual and tested PSD curves that could be employed to design the required TSU. Figure 1 demonstrates the simulation hypothesis of the theoretically design TSU. In Fig. 1a, the two chosen sediment units PSD curves, SU\#A and SU\#B, are theoretically assumed and used to mimic the actual targeted sediment unit (TSU). The simulation result is shown in Fig. 1b where the matching PSD is called the designed sediment unit (DSU). These shapes of the PSD curve can be used as quantifiable values, inherently revealing a dependency of grain size characteristics and depositional processes (Hunt 1984). Hence, the behavior 
Fig. 1 Hypothetical PSD curves matching

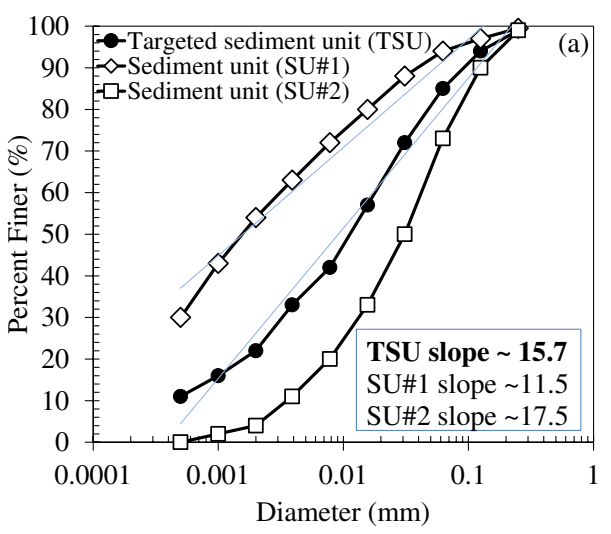

of the PSD curve is most likely plausible to use and estimate the proximity ratio of matching curves (DSU, TSU, and the SSU), as demonstrated in later next sections. The slope values of TSU and SSU could be plausibly used for evaluating this matching ratio. The slope values of TSU (15.7) and the two SUs $(A=11.5$ and $B=17.5)$, while, after simulation, the DSU slope is 15.0, which is well-matched with the TSU (15.7) (Fig. 1).

The next step done with the DSU is to experimentally be produced and tested through the mixture percentages determined of SU-A and SU-B, which is $40 \%$ of SU-A and $60 \%$ of SU-B, respectively.

In fine-grained sedimentary environments, the mineralogical component is essential component. The simulation procedure characterizes the particle-size distribution of finegrained sediment units that might differ in the mineralogy in different places. The mineralogy of the bay mud sediment unit, for instance, may differ in one spot from another due to the variability of depositional conditions. This means that two samples having the same PSD characterization might have different mineralogical components.

Muttashar et al. (2020) recommended using the plasticity characteristics, specifically the activity of clays, as a useful proxy to characterize the sediment mineralogy. They have considered the plasticity of fines and integrated with PSD characteristics to build their fine-grained sediment classification. The degree of plasticity index (PI), representing the difference between the liquid limit $(L L)$ and the plastic limit $(P L)$ (Terzaghi et al. 1996), implies a degree percentage of active (clay) minerals (i.e., the higher activity of clay minerals, the greater water capacity to be absorbed), whereas a low PI implies the converse. The liquid limits $L L$ are lines delineated based on the predominant clay minerals even though this sediment has the same as the Particle Size Distribution curve. For instance, $L L$ of the simulated bay mud Rancho Solano sediment unit ( $L L=55 \%)$ (Meehan 2006) is significantly less than $L L$ of the bay mud sediment unit in the Mississippi sediments, in which $L L$ reaches more than $100 \%$, despite the similarity of their particle size distribution curves
(Helwick and Bryant 1978). This variability was not attested in this paper. The current study focused on a certain degree of plasticity levels, low to medium, representing the dominant mineralogy of certain sediment groups of the study area taken as a case study. The proposed methodology is to mimic the behavior of the entire particle size distribution, with a specific, limited degree of plasticity level (low to medium), from real, selected sedimentary units.

\section{Method and materials}

\section{Site description and source sediments}

The study area is part of the sedimentary system of the lower Mesopotamian plain in the south of Iraq. The region is associated with the fluvial-marine processes of the Shatt al Arab delta that experiences the influence of the main rivers of Euphrates, Tigris, Shatt al Arab, and Karun (Jassim and Goff 2006). The fine-grained sediment units are the most fluvialmarine deposits of the eastern side of the Basrah region. Figure 2 shows sediment units that characterize a wide range of the estuarine environments of the lower part of the Mesopotamian basin in the Basrah region, which reflect complex transitional interacting sedimentary conditions. The closer sediments to the river mouth are, the more influence by the sea and tide conditions, the greater clayey and sandy sediment units are observed. In Fig. 2, four fine-grained sediment units covering the eastern Basrah side, around 50\% of the Basrah province, include coastal, tidal flat, marshes, flood plain, estuarine, and Inland Sabkha sediment unit, while the western Basrah side includes two coarse-grained sediment units; the alluvial fan and Sandy Dibdiba deposits, which are composite of sand and gravel of coarse-grained Pleistocene deposits. It is worth mentioning that the sediment units of the western Basrah side are not addressed in this study. The suggested simulation discipline of the study is to characterize the framework of the fine-grained sedimentary units of the eastern Basrah side. 


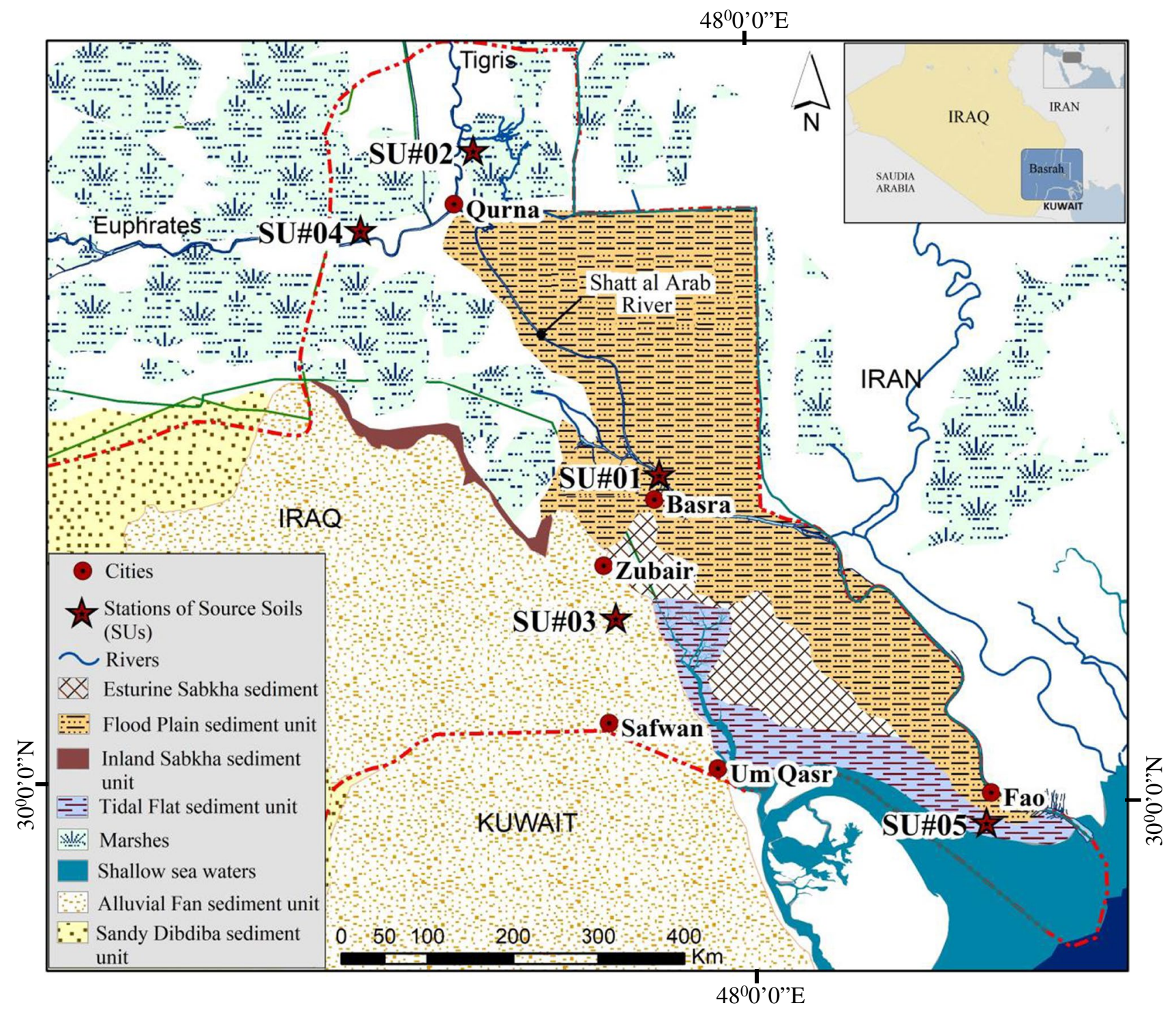

Fig. 2 Location map and samples adapted after (Jassim et al. 1990)

The surface fine-grained sediment units of the eastern Basrah side are of the Holocene age which is dominated by fresh, brackish, and saline marsh/lakes. The rivers and their reaches associated with natural crevasse-splays and natural levees crossed the marshes and lakes and passed through estuarine sabkha and intertidal strip along the coastal belt (Jassim and Goff 2006). The sediments shown in Fig. 2 reveal the interaction conditions of this fluvial-estuarine deposition system of the eastern Basrah side by a number of the fine-grained sediment units; (1) the Iraqi coastal zone (or the shallow seawater sediment unit), the unit is affected by the sedimentation and suppling processes of the Shatt Al-Arab River system and the tidal currents of the Khor Abdullah channel (Albadran 2000), and the fine particles (mud) deposit are the predominated sediment type in the area. (2) Tidal flat sediment, the unit is classified as silty clay sediments with high clay content reaching 75\% (Muttashar et al. 2010). (3) Estuarine and Inland Sabkha sediment; units are affected by the coastal processes predominantly, and consist of silt and clay at most, with very high salt content. (4) Marsh deposit unit; it represents the southern part of the Hammar Marshes, south of the Qurna region (north Basrah), which consists of silty clay and clayey silt with a few sands content of no more than $12 \%$. The sand particles are derived from aeolian dune, shell fragments, and/or mobile sand in the southwest desert (Aqrawi 1993b). It occupies about $17.41 \%$ of the Basrah area. (5) The flood plain sediment unit covers about $20.4 \%$ of the Basrah area and consists of clayey silt with little sand content that comes from the riverine deposits of the Tigris-Euphrates system. 
Thus, preferring the eastern Basrah side for this study is because it expose the diversity in terms of Holocene sedimentary environments presented by interacting of fluvialestuarine sediment system, as shown in Fig. 2. Samples of the current study cover the most predominated sediment units of these fine-grained sedimentary units. In addition, the interaction of these sediment units with the Palio-Pleistocene deposits units exposed on the western side, where the particle size is the most crucial agent to discern those units (Aqrawi 1993a).

Many references (Albadran and Al-Bahily 1999; Albadran and Hassen 2003; Muttashar et al. 2010, 2012; Al-Hamad et al. 2017; Al-Jaberi 2017; Al-Humaidan 2018; Al-Maliky 2018) were used to extract sediment data relevant to the study area. In addition, 14 sites were sampled and tested that have not been covered by the literature. The tests include the particle size distribution and mineralogy analyses performed at the University of Basrah at the Marine Science center and Physics department. The collected and resultant data of the fine-grained sediment units, including tidal flats, flood plain deposits of the river system, Sabkhas, marshes, were then reviewed, summarized, and illustrated in Table 1.

The table hence is a synopsis of the sediments units that the current research was focused. The data show mostly finegrained sediment units ranging from clayey silt to silty clay with a few sand particles. Regarding the mineralogy and composition, the collected samples reflect low to intermediate levels of plasticity with mostly non-active sediment behavior due to lower percentages of active smectite mineral groups.

For the simulation purposes of this research to construct various depositional environments, sediment specimen then picked from the tested samples to be "source samples" that have mainly silt- and clay-sized particles. These sources that include marshes, tidal flat, and natural levee channel sediment units reflect the interaction of the dominant processes of the riverine and estuarine sediment units of the lower Mesopotamian part.

\section{Source sediment units}

Five sediment samples were used as source sediments, as shown in Fig. 3, identified from different locations in the lower part of the Mesopotamian basin at the Basrah province, southern Iraq. These source sediments noted as SU\#01, SU\#02, SU\#03, SU\#04, and SU\#05 were sampled from Shatt al Arab River natural levees, marshes, Barjisia, Euphrates basin, and tidal area, respectively. The locations and index properties of the five sediment source units (SU) utilized in the current study, as listed in Table 2.

The assigned particle size distribution curves of the five sediment units, Fig. 3, predominantly are silt- and clay-sized particles.

The grain size analysis was performed under ASTM D422. These sediment data were used as the source sediment units for the mixture and mimic PSD curves of targeted sediment units picked from different places.

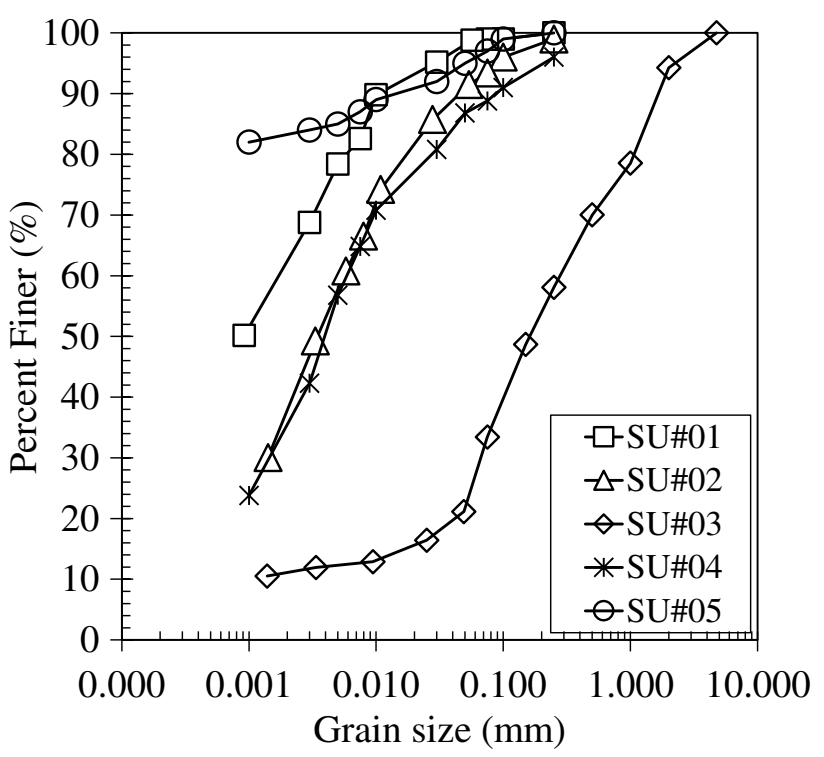

Fig. 3 Particle size distribution curves of the source sediments

Table 1 Characteristics of the sedimentary unit of the southern lower Mesopotamian part, the Basrah region

\begin{tabular}{|c|c|c|c|c|c|c|c|c|c|c|c|}
\hline \multirow[t]{2}{*}{ Sedimentary unit } & \multirow[t]{2}{*}{ Lithology } & \multicolumn{4}{|c|}{ Particle Size Distribution (\%) } & \multicolumn{6}{|c|}{ Clay Minerology } \\
\hline & & Gravel & Sand & Silt & Clay & $\mathrm{K}$ & I & $\mathrm{Ch}$ & $\mathrm{Ca}-\mathrm{M}$ & $\mathrm{M}-\mathrm{Ch}$ & At \\
\hline Flood plain & $\begin{array}{r}\text { Silt, clayey silt, } \\
\text { or sandy silty }\end{array}$ & 0 & $0-21$ & $72-85$ & $2.0-28$ & $13-25$ & $8-45$ & $4.0-23$ & $16-28$ & $15-53$ & $5-8$ \\
\hline Coastal zone (shallow seawater) & Silt, sandy silt & 0 & $5-34$ & $52-82$ & $12-25$ & $8-20$ & $5-20$ & $20-31$ & $3.0-26$ & $16-39$ & $0-24$ \\
\hline Tidal flat & Silty clay & 0 & $0-3$ & $46-53$ & $44-75$ & $6-18$ & $6.0-34$ & $0-7$ & 0.0 & $10-30$ & \\
\hline Marshes & Silty soil & 0 & $1-7$ & $68-75$ & $16-29$ & $13-30$ & $7.0-23$ & $0-18$ & $23-50$ & $17-36$ & $8-9$ \\
\hline Estuarine and Inland Sabkhas & Silty clay & 0 & 4.0 & 37 & 59 & 53 & 35 & - & 12 & - & \\
\hline
\end{tabular}

$K$, kaolinite; $I$, illite; $C h$, chloride; $C a-M$, Ca-montmorillonite; $M$ - $C h$, montmorillonite-chloride layers; At, attapulgite (palygorskite) 
Table 2 The used sediment index properties as source samples for mixture and mimic PSD curves of targeted (real) sediment units from different places around the world

\begin{tabular}{|c|c|c|c|c|c|}
\hline Source sediments & SU\#01 & SU\#2 & SU\#3 & SU\#4 & SU\#5 \\
\hline Location & Shatt al Arab River Basin & Tigris basin (marsh) & Barjisia site & Euphrates basin & Tidal Flat zone \\
\hline Sedimentary unit type & clayey Silt natural levees & clayey Silt marshes & $\begin{array}{l}\text { sandy Silt } \\
\text { River deposits }\end{array}$ & $\begin{array}{l}\text { sandy clayey Silt } \\
\text { Euphrates basin }\end{array}$ & silty Clay Tidal flat unit \\
\hline Specific Gravity Gs & 2.63 & 2.69 & 2.68 & 2.7 & 2.7 \\
\hline Liquid Limit (\%) & 48 & 25 & 74.5 & 55 & 51 \\
\hline Plasticity Index (\%) & 13 & 8.5 & 31 & 25 & 19 \\
\hline Fines $(\%)$ & 100 & 99.4 & 86.8 & 82 & 99 \\
\hline Clay Fraction $(\%)$ & 45 & 20 & 10 & 45 & 82 \\
\hline
\end{tabular}

Fines = percent of passing \# 200 sieve $(<0.075 \mathrm{~mm})$; clay fraction $=$ percent $<0.002 \mathrm{~mm}$

Table 3 Symbols of sediment units assigned and targeted in this study

\begin{tabular}{llll}
\hline Type of sediment unit (SU) & Symbols & & \\
\cline { 2 - 4 } & Target & Designed SU & Simulated SU \\
\hline Tidal flat sediment unit (TFSU) & T_TFSU & D_TFSU & S_TFSU \\
Natural levee sediment unit (NLSU) & T_NLSU & D_NLSU & S_NLSU \\
Bay mud sediment unit (BMSU) & T_BMSU & D_BMSU & S_BMSU \\
\hline
\end{tabular}

The process developed for this study simulated practically the entire PSD curve

\section{Targeted sediment units (TSU)}

As aforementioned, the intent of mixing different percentages is to develop particle size distribution curves simulating various sedimentary environments. There are three sedimentary units taken to simulate their PSD curves experimentally,, and their abbreviations used in this study referring to the target (T), designed (D), and simulated (S) sediment units of the three (real) sedimentary units, Table 3. They include silty clay of tidal flat sediment unit (TFSU), Rancho Solano silty clay of Bay Mud sediment unit (BMSU) (Meehan 2006), and sandy silt of natural levee unit (NLSU), as discussed in the subsequent sections.

The process developed for this study simulated practically the entire PSD curve.

\section{Experimental methods}

The hydrometer test was used to perform the grain size analysis of all collected samples according to (ASTM D422 2007).

The diagram shown in Fig. 4 concisely explains the general four steps used to develop a certain (targeted) sediment (TSU) that is aimed to study. The diagram started with the first step by identifying the PSD data of the TSU assigned from the literature. The second step is sampling sediment units from an area that is easy to approach and sampling. In this research, the sediment units from the Basrah region were picked, sampled, and analyzed. The purpose, as

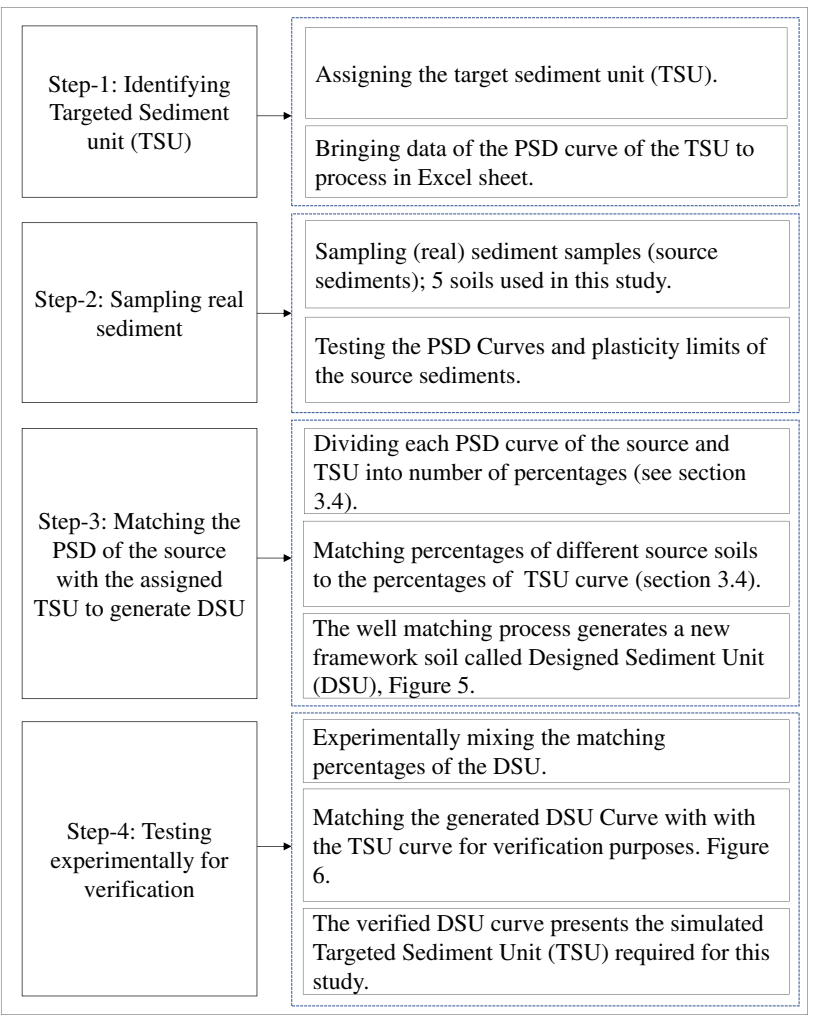

Fig. 4 Diagram concisely describing the practical simulation process of the targeted (required) sediment units 
aforementioned, is to use these sediment units (source soils) as reference data to generate a new soil that simulates the target sediment unit assigned in the first step. In this step, the particle size distribution curve for each selected sediment (source) and the target sediment unit is determined and then divided into the percentages, $5,10,15, \ldots, 85,90$, and $95 \%$ of passing, in an Excel sheet.

Thus, the third step in the diagram is attempting to match the particle size distribution (PSD) data of different source soils and TSU data. It is through estimating two (or more) PSD curves of source sediments to determine which PSD curves are the optimal matching to the target (real) curve. In this step, the matched PSD data of the source soils construct a new PSD curve called the DSU curve. Once generated, the percentages of the DSU curve (finer than percent), then, are tested in the laboratory through the mixing process. It is by conducting the grain size analysis using the hydrometer for this designed sediment unit, where the resulted PSD will then represent the simulated sediment unit (SSU). Step four is analyzing the computed PSD curve of the DSU to verify performance of the matching between the simulated (measured) PSD data of SSU and the designed (calculated) PSD data of DSU. Testing the matching between the SSU and the TSS curve is through testing the developed slope proximity ratio (1-[TSU/SSU]) that is a friction value refering to the variation amount between two slopes of the SSU and TSU curves, ranging between 0.0 and 1.0. The closer value to 1.0 is, the more plausible matching between the simulated (SSU) and targeted (TSS) sediment units is.

The source samples used to create mixtures with new PSD curves have different percentages of sand, silt, and clay including subdivisions of silt particle sizes $(0.075$ to $0.002 \mathrm{~mm}$ ), which characterizes the behavior of the finegrained sediment unit.

\section{Results and discussion}

\section{Simulated sediment units (SSU)}

The three sediment units (tidal flat, bay mud, and natural levee), Table 3 , were chosen to demonstrate the mixture technique. The simulated sediment samples and the different percentages of the source soils used in each unit design are presented in Table 4. For the three tested sediment units (marsh, buy mud, and natural levee), the ratios of slope proximity were $1.0,0.93$, and 0.99 , respectively, which are well matched.

The results of the three targeted and simulated PSD curves of the sedimentary environments (tidal flat, bay mud, and natural levee units) are illustrated in Fig. 5.

For the tidal flat sediment unit, TFSU, shown in Figs. $5 \mathrm{a}, 5 \mathrm{~b}$, and $5 \mathrm{c}$, the actual particle size distribution curve (T-TFSU) was simulated by mixing different percentages of the source samples. The closest matching percentages were achieved, and assigned these percentages to represent the designed curve. In this example, the optimal mix consisted of $55 \%$ of SU\#01, $45 \%$ of SU\# 2 .

For natural (channel) levee sediment unit, the simulated match for the Rancho Solano clay (Meehan 2006) and blends was $60 \%$ of SU\#01, $40 \%$ of SU\#3 required to achieve the optimal D-TFSU curve, as shown in Fig. 5d, $5 \mathrm{e}$, and $5 \mathrm{f}$.

For bay mud sediment unit, shown in Fig. 5g, 5h, and 5i. The designed PSD curve (D-BMSU) was determined by mixing $65 \%$ of SU\#04, 35\% of SU\#5, Table 3 from the source samples for simulation.

In fine-grained deposits (marsh and buy mud), the silt content (i.e., portions between 0.075 and $0.002 \mathrm{~mm}$ ) is an important portion of the PSD curve that controls the curve behavior and presents the slope of the PSD curve. The slope of the PSD curve characterizes the change of sediment types shaping the steepness of the curve. It ranges from clayey silt to silty clay sediments and forms steeper- to flattercurved shapes corresponding to the progression of the PSD curves from concave to convex curves, respectively. The silt content, hence, can be quantified as the slope of the PSD curve. As shown in Fig. 6b (buy mud), representing the silty clay unit, has a lower silt content (slope) value than that in Fig. 5b, which represents a clayey silt unit. Buy mud, thus, is a flatter PSD curve than that PSD curve of marshes clayey silt sediments. The higher the slope (silt portion) value, the steeper the grain-size curve. Hence, the sub-divisions of the silt portion of the PSD curves experimentally were well simulated and demonstrated, where at least four sub-sized divisions between 0.075 and $0.002 \mathrm{~mm}$ were identified and

Table 4 Optimal mixture percentages and Natural Log Slope of the three simulated sediment units

\begin{tabular}{llllll}
\hline Type of sediment unit (SU) & Optimal mixture percentages & \multicolumn{2}{l}{ Natural log slope of: } & & \multicolumn{2}{l}{$\begin{array}{l}\text { Variation ratio } \\
\text { (TSU/SSU) }\end{array}$} \\
\cline { 3 - 5 } & & Target SU (TSU) & $\begin{array}{l}\text { Designed SU } \\
\text { (SUD) }\end{array}$ & $\begin{array}{l}\text { Simulated } \\
\text { SU (SSU) }\end{array}$ \\
\hline Tidal flat sediment unit (TFSU) & 55\% of SU\#01+45\% of SU\#02 & 10.790 & 10.52 & 10.280 & 1.00 \\
Natural levee sediment unit (NLSU) & $60 \%$ of SU\#01+40\% of SU\#03 & 8.069 & 8.17 & 8.076 & 0.99 \\
Bay mud sediment unit (BMSU) & $65 \%$ of SU\#04+35\% of SU\#05 & 9.270 & 9.75 & 9.987 & 0.93 \\
\hline
\end{tabular}


Fig. 5 The three targeted sedimentary units including a tidal flat, $\mathbf{d}$ natural levee, and g bay mud; in addition to their associated source $(\mathbf{b}, \mathbf{e}$, and $\mathbf{h})$ and their designed PSD curves $(\mathbf{c}, \mathbf{f}$, and i), respectively
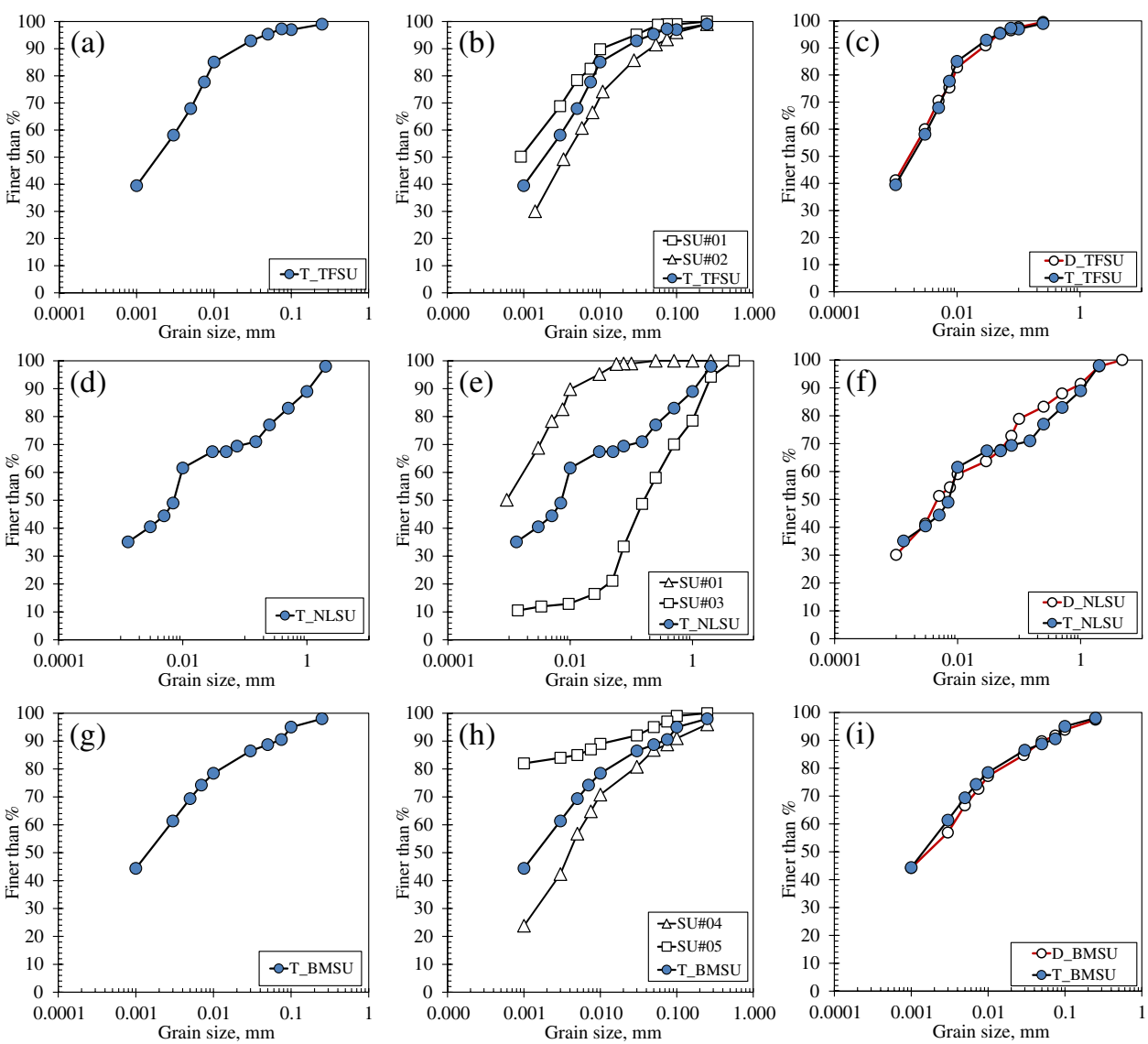
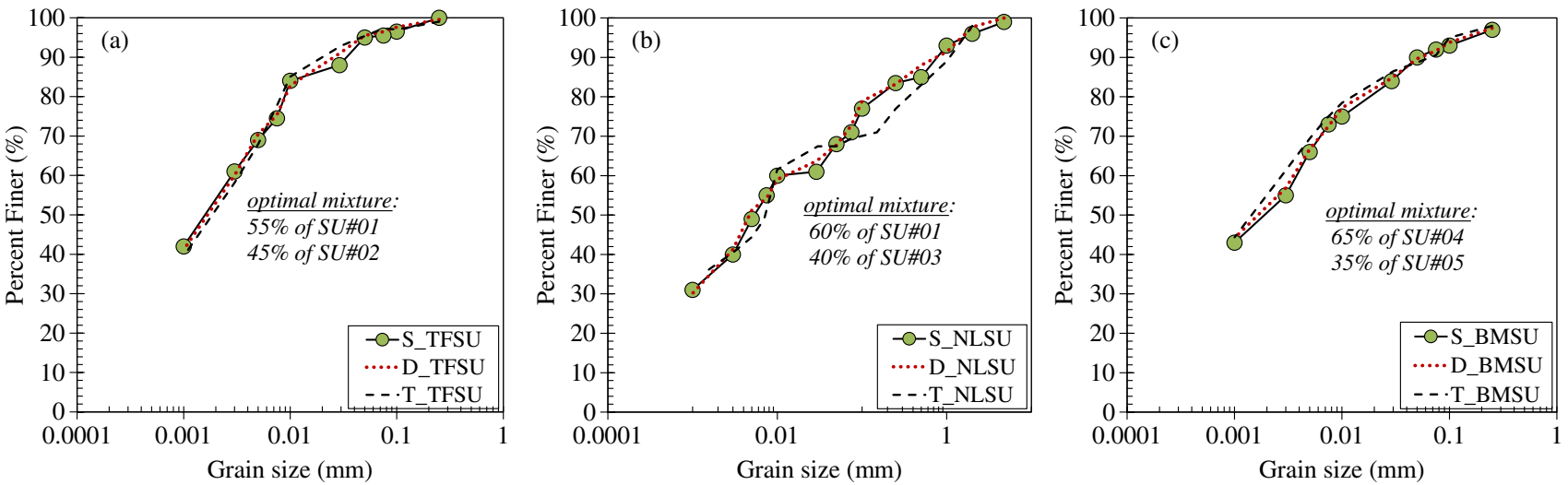

Fig. 6 Particle size distribution curves of targeted, designed, simulated a tidal flat sediment units (TFSU), b natural levee sediment unit (NLSU), and $\mathbf{c}$ bay mud sediment unit (BMSU)

predicted. This forward step allows a better estimate of the mixed materials predominantly having fine-sized materials.

In the same way, the coarse-grained deposits that have sand portions (i.e., the subdivision between 2 and $0.075 \mathrm{~mm}$ ) most likely representing the slope portion of the PSD curve. It also controls the behavior of the PSD curve and reflects changes from steeper to flatter PSD shapes and corresponding to the progression of the PSD curve from concave to convex. The higher the slope (sand portion) value, the steeper the particle-size curve. Hence, the experimental simulation method of this paper was well demonstrated. This step can also be used for a better estimate in event of blended sand-sized materials. The significance of the proposed practical method of this study not only allows simulating a certain sedimentary environment but also could be used to manipulate the engineering properties of weak sediments 
through changing poorly graded (well sorted) to well-graded (poorly sorted) sediments, in particular, for coarse-grained sediments. In fine-grained sediments, there are limitations related to the clay mineralogy (composition) that should be taken into consideration.

Designing the entire PSD curve is the primary step accomplished in this study was required, the next step presenting the mineralogical composition of the designed PSD curve as well.

\section{Characterizing the mineralogy}

The mineralogical composition might not be matter much for coarse-grained sediments, but it does for fine-grained sedimentary units, such as tidal flat, bay mud, or marsh mineralogical components, as aforementioned. Muttashar et al. (2020) recommended using the plasticity parameter as a useful proxy of the mineralogy of sediment. The source sediment units used for this purpose are classified as inorganic sediments with varying plasticities. The Casagrande plasticity chart was used to classify the type of plasticity of the simulated sediments, as shown in Fig. 7. The figure also reveals clay mineral types incorporated into the plasticity chart according to Holtz and Kovacs (1981). The figure shows that the data grouped along the A-line, which separates silt from clay. Silt plots below the A-line, while clay plots above the A-line.
To better understand the potential implications of using a plasticity chart for the mineralogy of sediments, the current study expanded the data points and extracted data from the literature (Bain 1971; Polidori 2007; Khalaf 2019; Muttashar et al. 2020). These added data covered a wide range of clay mineral types and plasticity values, such as Na-montmorillonite, Ca- montmorillonite, halloysite, and attapulgite. The data provide a better evaluation of various clay minerals and plasticity parameter correlation.

Due to using a broad range of datasets, the traditional (Casagrande) plasticity chart is shown limitations with lower resolution to prescribe the data points. The data groups having $L L$ values less than $50 \%$ are categorized indistinctly which makes it difficult to be recognized, as shown in Fig. 7. The plasticity chart, therefore, was modified using a logarithmic scale of both $\mathrm{x}$ - and $\mathrm{y}$-axes. It shows better resolution and more discerned categorizes of various minerals of sediment having medium-low plasticity values ( $L L$ is less than $50 \%)$ and ultra-high values ( $L L>700 \%)$. The modified plasticity chart was able to prescribe and predict data points of platey and non-platey mineral groups. The modified plasticity chart with the same data points is presented in Fig. 8. The data revealed that the groups of clays were well clustered, and they formed a trending relationship that defined the PI as a power function of LL. The liquid limit was used to identifying the low $(L L<30 \%)$, moderate $(30 \%<L L<50 \%)$, high $(50 \%<L L<70 \%)$, and very high $(L L>70 \%)$ levels of plasticity. The distribution of the clay minerals groups in
Fig. 7 Plasticity chart for the sediments from this study, where $\mathrm{MH}$ is high plasticity silt and $\mathrm{CH}$ refers to high plasticity clay

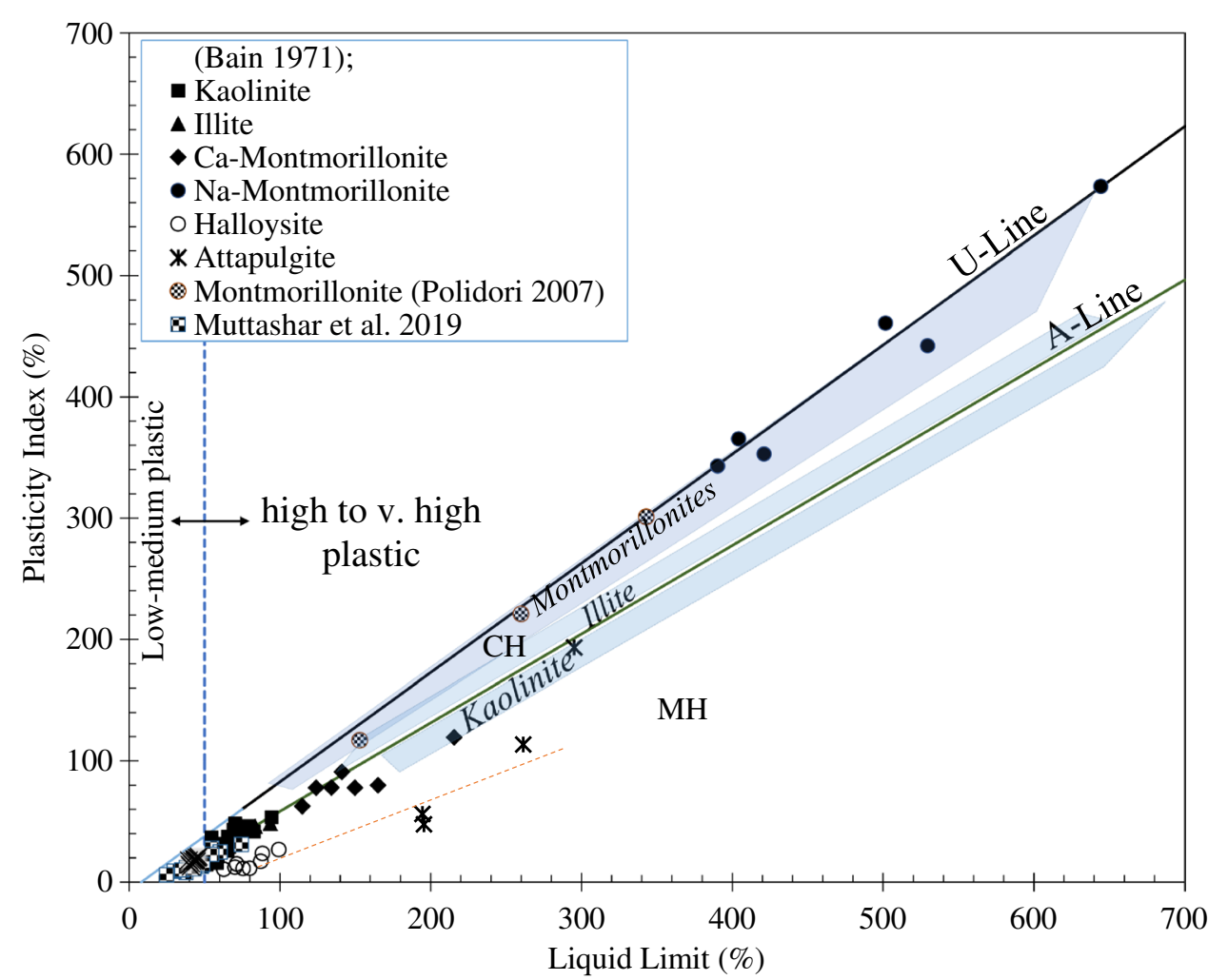


Fig. 8 Modified plasticity chart

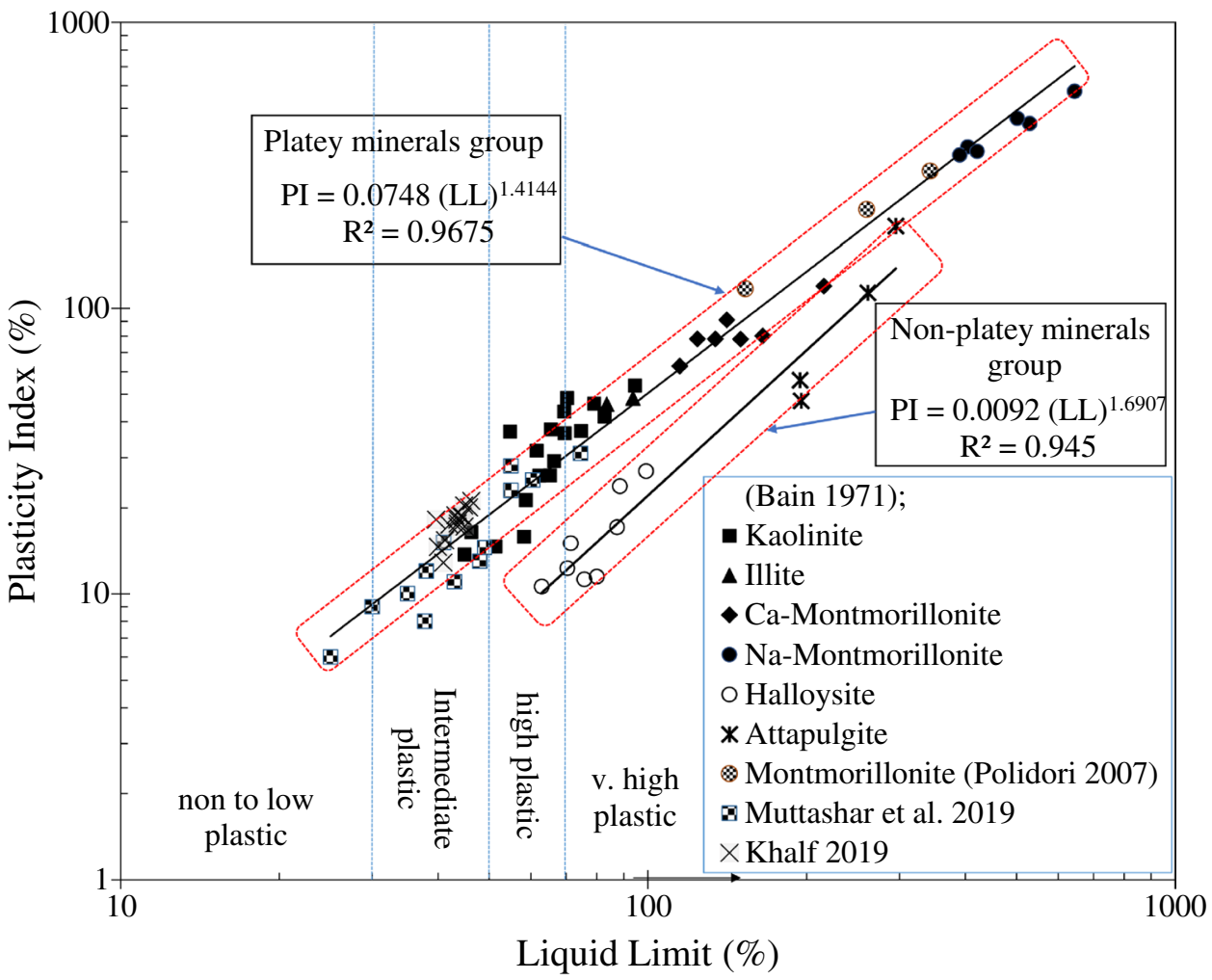

Fig. 8 shows two power function lines that correspond to the two clay platey and non-platey groups. The first trend line is described by Eq. 1. This line represents the predominant relation associated with the main large clay groups (platey minerals). The second line in the figure is given by Eq. 2, which is related to the less predominant clay groups (nonplatey minerals), such as halloysite and attapulgite.

$P I=0.0748(L L)^{1.4144}$ (platey clay minerals group)

$P I=0.0092(L L)^{1.6907}$ (non-platey clay minerals group)

Data in Fig. 8 facilitates a better understanding of the physical behavior of different sediment types. It shows the plasticity ( $L L$ and $P I$ ) parameters are potential proxies to discern and plausibly identify the type of clay minerals.

The majority of the sediment samples were classified as either low plasticity silt (ML) or plasticity clay (CL), where the division between low plasticity and high plasticity being at $L L=50 \%$. The samples mostly fall within the kaolinite, and illite zones (the platey clay minerals) as illustrated in Fig. 8.

The rest of the data were located within the halloysite mineral zone (a non-platey clay minerals area). These clay minerals (platey and non-platey minerals) have different effects on the Atterberg limits values of the sediments
(Mitchell James 1993; Polidori 2007). The non-platey minerals cause a high plastic limit, high liquid limit, and in turn result in low plasticity index, while the platey clay minerals entail a low plastic limit, high liquid limit, and as a result, high plasticity index, relatively. The location of fine-grained sediment, relative to the U-line or A-line, indicates the mineralogy of the specimen. Sediments that plot near the A-line typically have clay minerals consisting of illite/mica and kaolinite clay. Sediments that plot near the U-line are very high plasticity index soils composited primarily of smectite clay minerals group such as montmorillonite.

Sediments with halloysite and chloride are located below A-Line. The sediments having halloysite clay minerals tend to be indicative to the tropical riverine environment, driven from residual and volcanic processes (Wesley 2010). These sediments are characterized as having high clay fractions but have a relatively low degree of plasticity. In the plasticity chart, this can be seen in those data points of sediments spotted in the halloysite zone. These points have PI values that increase as $L L$ increases at a much slower rate relative to other clay minerals.

In general, Mitchell James (1993) demonstrated that the clay fraction of soil has little effect on PL but has a significant positive association with $L L$, and consequently, the clay fraction has a high correlation with PI as well. Thus, it could be held that $L L$ correlates well with the amount of clay, while $P L$ is possibly correlated to the type of clay minerals. These $L L$ and $P L$ correlations imply that 
sediment units may have the same $L L$ due to the same amount of clay fraction, but might have different $P L$ values due to various clay minerals, which results in different $P I$ values. Furthermore, halloysite and kaolinite have the same composition and were formed under similar conditions. Both halloysite and kaolinite belong to the feldspar mineral group, yet halloysite has a greater amount of water molecules between layer units than that in kaolinite (Lázaro 2015). This increase in the number of water molecules could be a further reason for the PL of halloysite being higher than that of kaolinite. However, the halloysite loses this amount of water molecules readily at heating and transfers to kaolinite. This could be the reason halloysite is shown in the kaolinite zone on the plasticity chart (Fig. 8).

\section{Conclusions}

This study proposed a mixture procedure to experimentally construct a real (target) sedimentary unit, common in estuarine and riverine depositional environments, with emphasizing on fine-grained sediment units. The study was able to mimic the three most common sediment units, tidal flat, buy mud, and natural (channel) levee sediments selected from the eastern Basrah side at the lower Mesopotamian plain, southern Iraq. The matching between particle size distribution (PSD) curves of simulated sediment units (SSU) and target sediment unit (TSU) was verified by applying the slope proximity ratio. For the three tested sediment units (marsh, buy mud, and natural levee), the ratios of slope proximity were $1.0,0.93$, and 0.99 , respectively, which are well matched. Regarding the mineralogy composition factor, the study is relied upon the consistency limits ( $L L$ and $P I$ ) to determine the dominant clay minerals. The study proposes a modified plasticity chart by using a logarithmic scale for both axes of the chart (e.g., $\log (P I)$ as a function of $\log (L L))$. Compared with the traditional plasticity chart, the proposed modified plasticity chart much better demonstrates a wide range of the data points $(<20$ to $>700)$ that have non-low plastic behavior to very and ultra-high level of plasticity degrees, such as some kaolinites to Na-montmorillonites, respectively. Furthermore, based on the modified plasticity chart, two power functions were developed for determining the platy and non-platy minerals. These predictive relations support using the consistency limits as reliable means to proxy the mineralogy.

The plan requires programming the generalized steps of the mixture procedure PSD curve mentioned in Sect. 3.4 of this study within a computational program that will work on sedimentary environments more than what was calculated in this research.
Acknowledgements The authors would like to thank the researchers in the Engineering Geology and sediments labs at the University of Basrah for assisting in testing and technical advice.

Funding This study is funded by the Soil Mechanics Labs at the Civil Engineering Dept of the University of Kentucky in the USA.

\section{Declarations}

Conflict of interest The authors declare no competing interests.

\section{References}

Albadran BN (2000) Clay mineral distribution in selected locations along the Tigris and Shatt Al-Arab Rivers, South Iraq. Marina Mesopotamica 15(2):439-452

Albadran BN, Al-Bahily, NK (1999) Some aspects of geotechnical properties of the Shatt al Arab river sediments near Basrah city, Southern Iraq. Mesopotamian Journal of Marine Science (Marine Mesopotamica) 14 (1):109-117

Albadran BN, Hassen WF (2003) Clay mineral distribution of supratidal region, South of Iraq. Marina Mesopotamica 18(1):25-33

Al-Hamad S, Albadran BN, Pournelle J (2017) Geological History of the Shatt Al-Arab River, South of Iraq. LAP Lambert Academic Publishingp. 116. ISBN: 978-3-330-32102-1

Al-Humaidan ZA (2018) Sediment logical, Mineralogical and fauna study of marine sediments NW of the Arabian Gulf, southern Iraq.M.Sc.Thesis, Science, Co. Basrah, Uni. Iraq.PP.178., Unpubl. MSC. Thesis, College of Science, The University of Basrah, Iraq

Al-Jaberi MH (2017) Clay minerals variations in quaternary sediments of Basrah City-Iraq Journal of Earth Science Research-Published by Canadian Center of. Sci Educ 6:41-55

Allen PA, Armitage JJ, Whittaker AC, Michael NA, Roda-Boluda D, D'Arcy M (2015) Fragmentation model of the grain size mix of sediment supplied to basins. J Geol 123(5):405-427

Allen PA, Michael NA, D'Arcy M, Roda-Boluda DC, Whittaker AC, Duller RA, Armitage JJ (2017) Fractionation of grain size in terrestrial sediment routing systems. Basin Res 29:180-202

Al-Maliky FS (2018) Improvement of Cohesive and Sub-base Soils at Fao Port in Basrah Governorate -Southern of Iraq by Addition of Compound Polymers and Cement., Unpubl. MSC. Thesis, College of Science, The University of Basrah, Iraq

Aqrawi AA (1993a) Palygorskite in the recent fluvio-lacustrine and deltaic sediments of southern Mesopotamia. Clay Miner 28(1):153-159

Aqrawi, AA (1993b) Recent sediments of the Tigris-Euphrates Delta: the southern marshlands (Ahwar) (Doctoral dissertation, University of London, Imperial College of Science, Technology and Midince. UK

ASTM D422 (2007) Standard test method for particle-size analysis of soils. Standard test method for particle-size analysis of soils. Annual book of ASTM standards, West Conshohocken, PA

Azidane H, Michel B, Bouhaddioui ME, Haddout S, Magrane B, Benmohammadi A (2021) Grain size analysis and characterization of sedimentary environment along the Atlantic Coast, Kenitra (Morocco). Mar Georesour Geotechnol 39(5):569-576

Bain J (1971) A plasticity chart as an aid to the identification and assessment of industrial clays. Clay Miner 9(1):1-17

Beierle BD, Lamoureux SF, Cockburn JM, Spooner I (2002) A new method for visualizing sediment particle size distributions. J Paleolimnol 27(2):279-283 
Blott SJ, Pye K (2001) GRADISTAT: a grain size distribution and statistics package for the analysis of unconsolidated sediments. Earth Surf Process Landf 26:1237-1248

Brierley GJ, Fryirs KA (2013) Geomorphology and river management: applications of the river styles framework. John Wiley and Sons, Inc

Caldwell RL, Edmonds DA (2014) The effects of sediment properties on deltaic processes and morphologies: a numerical modeling study. J Geophys Res Earth Surf 119:961-982

Cheng Z, Liu H (2015) Digital grain-size analysis based on autocorrelation algorithm. Sed Geol 327:21-31

Edmonds DA, Slingerland RL (2010) Significant effect of sediment cohesion on delta morphology. Nat Geosci 3:105-109

Feng H-c, Zhang W, Zhu Y-l, Lei Z-y, Ji X-m (2017) Sampling Surface Particle Size Distributions and Stability Analysis of Deep Channel in the Pearl River Estuary. China Ocean Eng 31:299-307

Gammoudi A, Essefi E, Rigane H (2019) Variability of the grainsized fractions during the last three millennia within the sedimentary fillings of the saline system of Mhabeul: the Holocene cyclostratigraphy. Arab J Geosci 12(9):1-11. https://doi.org/10. 1007/s 12517-019-4472-3

Helwick JS, Bryant WR (1978) Geotechnical characteristics of Mississippi Delta sediments, southeast Louisiana. Mar Georesour Geotechnol 3(2):183-198

Holtz RD, Kovacs WD (1981) An introduction to geotechnical engineering. vol Monograph

Hunt RE (1984) Geotechnical engineering investigation manual. McGraw-Hill New York, New York

Jassim SZ,Goff JC (Eds.) (2006) Geology of Iraq. Dolin, Prague and Moravian Museum, Brno, Czech Repulic, distributed by Geological Society of London. ISBN 80-7028-287-8

Jassim SZ, Hagopian DH, AL-Hashimi HA (1990) Geological map of Iraq. Scale 1: $1000000.2^{\text {nd }}$ Edition, S. E. of Geological Survey and Mineral Investigation. Baghadad, Iraq

Khalaf AM (2019) The organic matter distribution and its effects on the geotechnical properties of the surface bearing strata in selected areas of Basrah governorate/southern Iraq. Unpubl. MSC. Thesis, College of Science, The University of Basrah, Iraq

Lázaro BB (2015) Halloysite and kaolinite: two clay minerals with geological and technological importance. Rev Acad Cienc Exactas Físicas Químicas Cienc Naturales Zaragoza 70:7-38. ISSN: 0370-3207

Meehan C (2006) An experimental study of the dynamic behavior of slickensided slip surfaces. Ph. D. thesis, Virginia Tech

Mitchell James K (1993) Fundamentals of soil behavior. John Wiley and Sons, Inc., $2^{\text {nd }}$ Edition, New York
Muttashar, WR (2019) Effects of sepositional processes on strength and compressibility of sediments using elastic shear wave velocity. $\mathrm{Ph} . \mathrm{D}$ Thesis, Earth and Environmental Sciences, The University of Kentucky. USA. https://uknowledge.uky.edu/ees_etds/66

Muttashar WR, Al-Amari F, Al-Hussein M (2012) Geotechnical analysis for types of surficial fine-grained Soils at the eastern side of Basrah region, Southern Iraq. J Univ Thi-Qar 7:1-11

Muttashar WR, Al-Tai M, Al-Amari F, Ali A (2010) Geotechnical properties of some tidal flat sediments of Khor-Abdullah coast, southern Iraq, Mesopotamian. J Mar Sci 25:75-82

Muttashar WR, Bryson LS (2020) Constitutive model for predicting stress-strain behavior of fine-grained sediments using shear-wave velocity. Mar Georesour Geotechnol 38(8):896-910

Muttashar WR, Bryson LS, McGlue M, Woolery E (2020) The integration of grain-size distribution and plasticity parameters for characterizing and classifying unconsolidated dine-grained sediments. Bull Eng Geol Env 79(2):925-939. https://doi.org/10.1007/ s10064-019-01588-x

Muttashar WR, Bryson LS, Woolery E (2019) Determining the effects of depositional processes on consolidation behavior of sediment using shear-wave velocity. Mar Georesour Geotechnol 37(9):1032-1043. https://doi.org/10.1080/1064119X.2018.15249 53

Polidori E (2007) Relationship between the Atterberg Limits and Clay Content. Soils Found 47:887-896

Terzaghi K, Peck RB, Mesri G (1996) Soil mechanics. Wiley, New York

van B Weaver A, Stone A (1980) Distinguishing sub-environments of sediment deposition in reservoirs using particle size distribution parameters. J Limnol Soc South Afr 6(1):59-65

Wesley LD (2010) Geotechnical engineering in residual soils. John Wiley and Sons, Inc. https://doi.org/10.1002/9780470943113. index

Yang S, Solheim A, Forsberg C, Kvalstad T, Feng X, Li A, Urgeles R (2009) Geotechnical properties of river-fed sediments compared with glacier-fed sediments. Mar Georesour Geotechnol 27:281-295

Zhang Z, Qiu H, Zhang X, Zhang H (2017) Application and analysis of measurement model for calibrating spatial shear surface in triaxial test. In: IOP Conference Series: Materials Science and Engineering,. vol 1. IOP Publishing, p 012062

Zhu B-Q, Yu J-J, Rioual P, Ren X-Z (2014) Particle size variation of aeolian dune deposits in the lower reaches of the Heihe River basin, China. Sediment Geol 301:54-69 